\title{
CONTROL OF INFECTION OF BIOMPHALARIA ALEXANDRINA (EHRENBERG, 1831) WITH SCHISTOSOMA MANSONI SAMBON, 1907 USING EUCALYPTUS CAMALDULENSIS
}

\author{
Hanan S. Mossalem ${ }^{1}$, Mohamed R. HabiB ${ }^{1 *}$, Mosad A. GHareeb ${ }^{2}$ \\ ${ }^{1}$ Medical Malacology Laboratory, Theodor Bilharz Research Institute, Giza 12411, Egypt \\ (e-mail:m.habib@tbri.gov.eg, hanan.mossalem@yahoo.com) \\ ${ }^{2}$ Department of Medicinal Chemistry, Theodor Bilharz Research Institute, Giza 12411, Egypt \\ (e-mail: m.ghareeb@tbri.gov.eg) \\ *corresponding author
}

\begin{abstract}
Schistosomiasis infection can be interrupted if the development of miracidia to cercariae in Biomphalaria alexandrina (Ehrenberg) is blocked. This requires an efficient snail's antioxidant system which can be complemented with an exogenous antioxidant source to alleviate the oxidative stress of infection. For this purpose, leaves of Eucalyptus camaldulensis were air-dried, extracted with aqueous methanol (85\%) and defatted with petroleum ether. The obtained defatted extract was used to prepare extracts with different solvents. Among these, ethyl acetate showed the highest antioxidant activity and was chosen for the experiments. The effect of ethyl acetate extract on the infection, survivorship, as well as levels of malondialdehyde (MDA), catalase (CAT) and reduced glutathione (GSH) in B. alexandrina were measured in control, untreated infected and treated infected snails on 1, 10, and 30 days post infection (dpi). The snails exposed to ethyl acetate extract showed a significant reduction in the infection rate compared to those infected and untreated. Moreover, the extract decreased the level of MDA and increased CAT and GSH activities in the haemolymph and tissues of the treated snails. The results suggest that ethyl acetate extract from leaves of E. camaldulensis can be used as an antiparasitic compound against the intramolluscan phase of S. mansoni Sambon, 1907.
\end{abstract}

KEY WORDS: ethyl acetate extract, Eucalyptus camaldulensis, Biomphalaria alexandrina, Schistosoma mansoni, oxidative stress, antioxidant activity

\section{INTRODUCTION}

Schistosomiasis is an acute and chronic disease which affects millions of people in tropical and subtropical countries. Most of the suffering people (92\%) are residents of 41 African countries (WHO 2017). The schistosome life cycle is complex and requires two hosts; a human definitive host and an intermediate snail host. Schistosoma mansoni Sambon, 1907 depends on snails of the genus Biomphalaria Preston, 1910 as its intermediate host. Within Biomphalaria, the parasite develops from miracidia, the snails' infective larvae, to cercariae, the human infective stage (MEULEMAN 1971, MORGAN et al. 2001, BAYNE 2009). Up to date, no effective vaccine has been found against schistosomiasis and the disease control depends entirely on praziquantel. Laboratory tests have shown an emerging resistance to the drug (FALLON \& DOENHOFF 1994, DOENHOFF et al. 2009). Therefore, there is a continuous need for new control methods such as blocking the parasite's development within snails to decrease disease transmission.

In Egypt, according to a recent estimate, the average prevalence of $S$. mansoni infection in five Egyptian governorates in the Nile Delta region is $10.7 \%$; schoolchildren aged $6-15$ years were examined using the Urine-Circulating Cathodic Antigen 
cassette assay (HAGGAG et al. 2017). This prevalence rate is considerably higher than expected and has many indications. For example, it may indicate a recent human-water contact in spots with abundant occurrence of infected Biomphalaria alexandrina (Ehrenberg, 1831), the main intermediate host for $S$. mansoni in Egypt (LOTFY et al. 2005, MOHAMED et al. 2012, ABOU EL-NAGA 2013). Thus, efforts should be directed to identifying such spots and to take appropriate measures. Although disease reduction and elimination using snail control requires long-term and repetitive applications, most of the currently recommended control strategies emphasise mass drug administration using praziquantel together with snail control (KING \& BERTSCH 2015). Widespread snail control reduced prevalence by $92 \pm 5 \%$ ( $\mathrm{N}=$ $19)$ vs. $37 \pm 7 \%(\mathrm{~N}=29)$ for programmes using little or no snail control (SOKOLOW et al. 2016).

Snail control using the currently recommended molluscicide, nicolsamide, has side-effects on non-target aquatic organisms and is expensive for many endemic countries. Modern and innovative control tools are needed to overcome the disadvantages of nicolsamide or any other synthetic molluscicide. Tackling the parasite development within the snail hosts would stop the infection spread in snails and thus prevent human infection. For this purpose, it is important to know the requirements of intramolluscan development of S. mansoni (BAYNE 2009).

Schistosome infection presents an immune challenge to snails and in response the snails' haemocytes produce reactive oxygen species such as hydrogen peroxide $\left(\mathrm{H}_{2} \mathrm{O}_{2}\right)$ to kill the parasite (BAYNE et al. 1980, HAHN et al. 2001). Larvae of S. mansoni have their own defence mechanism which involves several antioxidant enzymes such as glutathione-S-transferase, $\mathrm{Cu} / \mathrm{Zn}$ super oxide dismutase (SOD), glutathione peroxidase and peroxiredoxins (ZELCK \& VON JANOWSKY 2004, WU et al. 2009). The outcome of this battle between the snail's oxidant system and the parasite's antioxidant defines the susceptibility or resistance phenotype of Biomphalaria (MONÉ et al. 2011, MiTTA et al. 2017). The immune system can be a target for interferences to shift the balance in the snail's favour to help overcome the parasite.

Natural compounds can be added to the snails' water to act as exogenous antioxidant sources which enhance the immune system and help to kill the invading parasite larvae. Natural plant products have been used for thousands of years as medicines, cosmetics, food additives and flavouring substances with little or no harmful effects. The effect of plants used for medicinal purposes is based on compounds contained in their extracts. Plant extracts are rich in alcohols, esters, aldehydes, ketones, carbohydrates, terpenes, and polyphenols which account for the plants' antioxidant effects. A wide range of medicinal plants has proven sufficient in treating ROS (reactive oxygen species)-mediated disorders by restoring the balance between oxidative stress and antioxidant system within organisms. A study on the effect of extracts from Punica granatum has shown its potential as an immunostimulant to block the development of S. mansoni in B. alexandrina (MOSSALEM et al. 2017). In this paper we used Eucalyptus camadulensis which is widespread in Egypt. Eucalyptus is a rich source of polyphenols, terpenoids, eucalyptol and cineole (GHISALBERTI 1996, LAMBERT et al. 2001, DEY \& MiTRA 2013). Essential oils from E. camaldulensis are used to produce soaps, detergents, lotions and perfumes and also to flavour foods and beverages (CARVAlHo et al. 2016). The plant has also an antimicrobial potential against gram-positive bacteria (NEElam et al. 2014) and anti-inflammatory (PINO et al. 2002), antitermitic (SIRAMON et al. 2009), larvicidal and mosquito repellent effect (BATISH et al. 2008, NERIO et al. 2010), as well as antioxidative and antiradical properties (SIRAMON \& OHTANI 2007). The antioxidant effect of the leaf extract from E. camaldulensis was determined and tested on B. alexandrina infected with $S$. mansoni to evaluate its effect on the infection rate and survivorship of the snails.

\section{MATERIAL AND METHODS}

\section{PLANT MATERIAL}

Fresh leaves of Eucalyptus camaldulensis Dehnh were collected in Giza Governorate in May 2016 and used for the extraction process. Identification and authentication of the collected material was carried out by Prof. Dr. WAFAA AMER, Professor of Plant Taxonomy, Faculty of Science, Cairo University, Giza, Egypt, using some of the collected leaves.

\section{PLANT EXTRACTION AND FRACTIONATION}

\section{Chemicals and reagents}

All solvents and reagents used were of analytical grade. 1,1'-diphenyl-2-picryl-hydrazyl (DPPH), and ascorbic acid were obtained from Sigma-Aldrich, UK. All other solvents used in the current research work were obtained from El-Nasr Pharmaceutical Chemicals Co., Egypt.

Air-dried powdered leaves of E. camaldulensis (1.5 $\mathrm{Kg}$ ) were soaked in four litres of aqueous methanol $(85 \%)$ for three days at room temperature $\left(25 \pm 2{ }^{\circ} \mathrm{C}\right)$. 
The crude methanolic extract (ME) was concentrated in rotational evaporator and the resulting extract $(210 \mathrm{~g})$ was defatted with petroleum ether $\left(60-80^{\circ} \mathrm{C}\right)$ $(1.5 \mathrm{~L})$ to obtain petroleum ether extract $(25 \mathrm{~g})$. The defatted $85 \%$ ME (175 g) was suspended in distilled water, and extracted successively with $1.5 \mathrm{~L}$ of dichloromethane, ethyl acetate $(2 \mathrm{~L})$, and $n$-butanol (2 L), to obtain methylene chloride (40 g), ethyl acetate (15 g), n-butanol (50 g), and water (55 g) extracts. The obtained extracts were weighed and stored for further analyses.

\section{1,1'-diphenyl-2-picryl-hydrazyl (DPPH) radical scavenging activity of the extracted materials}

The free radical scavenging antioxidant activity was determined according to the reported procedures, using ascorbic acid as standard (GHAREEB et al. 2014, SHOEB et al. 2014).

\section{EFFECT OF E. CAMALDULENSIS EXTRACT ON SURVIVORSHIP, INFECTION RATE AND OXIDATIVE PARAMETERS OF B. ALEXANDRINA}

\section{Snail maintenance and S. mansoni infection}

B. alexandrina used in this study were descendants from populations collected from irrigation schemes in Giza Governorate, Egypt. The snails were maintained at room temperature $\left(25 \pm 1^{\circ} \mathrm{C}\right)$ in the Medical Malacology Laboratory, Theodor Bilharz Research Institute, in plastic aquaria $(16 \mathrm{~cm}$ width $-23 \mathrm{~cm}$ length $-10 \mathrm{~cm}$ depth) containing dechlorinated tap water. The water was changed every four days and the snails were fed with lettuce leaves on a daily basis. A preliminary experiment was done by exposing B. alexandrina to different concentrations of ethyl acetate extract of E. camaldulensis (10 ppm - 1,000 ppm) to test the toxicity of the extract. Mortality rate was the toxicity end point for the extract. At the highest concentration $(1,000 \mathrm{ppm})$ used, no mortality was recorded among the snails. Thus, this group was excluded from the study design and the following three groups of adult $B$. alexandrina $(10-12 \mathrm{~mm}$ in diameter), three replicates each of 40 snails per group, were used as follows:

1. Group 1 (control): snails in dechlorinated water only.

2. Group 2 (infected untreated): snails infected with S. mansoni (8-10 miracidia/snail) without exposure to E. camaldulensis extract.

3. Group 3 (infected treated): snails continuously exposed to E. camaldulensis extract starting one month before infection with $S$. mansoni till the end of the experiment.

The time of exposure to the extract was adjusted so as to establish all the experimental groups on the same day. Stock solution of E. camaldulensis extract was prepared by dissolving $0.2 \mathrm{gm}$ of the extract in $0.5 \mathrm{ml}$ of dimethyl sulphoxide (DMSO), and diluted to $200 \mathrm{ml}$ with distilled water. Further dilutions were made to obtain $200 \mathrm{ppm}$ concentration to be used in the treatment experiments $(200 \mathrm{ppm}$ was selected based on the DPPH results, the concentration which produced the highest radical scavenging activity). The same volume of DMSO was added to the control group (the percent of DMSO in all the groups did not exceed $0.5 \%$ ). The solutions were changed every two days to ensure adequate exposure of the snails to the extract. In a preliminary experiment we did not find any toxic effect of the extract on normal $B$. alexandrina; consequently we focused only on the control (water containing DMSO only), infected untreated (water containing DMSO) and infected treated (extract solution containing DMSO) groups to compare the effect of the extract on infection and antioxidant system.

Levels of oxidative parameters were determined in the tissue and haemolymph of B. alexandrina (in triplicates each of 10 snails) before and after treatment with the extract of E. camaldulensis on days 1, 10 and 30 post infection (dpi). Besides, survivorship and infection rates were also determined.

\section{Survivorship and infection rate}

Starting from day 21 post miracidial exposure, the snails were examined individually and repeatedly for cercarial shedding in multi dishes under artificial light for two hours in $2 \mathrm{ml}$ of dechlorinated tape water per snail. All snails that died during the prepatent period were crushed between two slides and inspected under a microscope for immature parasite stages (CHERNIN \& DUNAVAN 1962). The snail's infection rate was calculated at the end of the experiment by dividing the number of shedding snails and those which were positive on crushing (inspected after death during prepatent period) by the number of exposed snails; the survivorship was calculated by dividing the number of snails at first shedding by the total number of exposed snails (Yousif et al. 1998).

\section{ESTIMATION OF OXIDATIVE STRESS AND ANTIOXIDANT PARAMETERS}

Haemolymph and whole tissue samples were collected in triplicates (ten snails each) from each experimental group on 1, 10 and 30 dpi from the control, infected untreated and infected treated groups (30 snails total per time-point and per group). The tissue samples were washed in distilled water, weighted and homogenised in PBS (phosphate buffer solution; $50 \mathrm{mM}$ potassium phosphate, $\mathrm{pH} 7.5$ and $1 \mathrm{mM}$ EDTA) in a 1:10 weight to volume using a glass homogeniser. The tissue homogenates were 
centrifuged at $4,000 \mathrm{rpm}$ for 15 minutes at $4{ }^{\circ} \mathrm{C}$. The resulting supernatant and haemolymph were used to calculate the concentration of malondialdehyde (MDA) based on SATOH (1978) using lipid peroxide kit (Biodiagnostic Company, Dokki, Giza, Egypt; Cat. No. MD 2529), catalase (CAT) activity based on the method of AEBI (1984) using catalase assay kit (Biodiagnostic Company, Dokki, Giza, Egypt; Cat. No. CA 2517), and reduced glutathione (GSH) concentration using colorimetric GSH kit (Biodiagnostic Company, Dokki, Giza, Egypt; Cat. No. GR 2511) based on BEUTLER et al. (1963).

\section{RESULTS}

\section{ANTIOXIDANT EFFECT OF E. CAMALDULENSIS}

The DPPH free radical scavenging activity of different solvent extracts of $E$. camaldulensis showed that $\mathrm{SC}_{50}$ values (concentration of sample required to scavenge $50 \%$ of DPPH radicals) of the tested extracts were $65.60,1.58,30.64$, and $102.37 \mu \mathrm{g} / \mathrm{ml}$, for the $85 \% \mathrm{ME}$, ethyl acetate, $n$-butanol and water extracts respectively, compared to ascorbic acid as standard with $\mathrm{SC}_{50}$ value of $7.50 \mu \mathrm{g} / \mathrm{ml}$, and no activity was recorded with the petroleum ether or methylene chloride extracts (Table 1). The results indicate that the ethyl acetate extract was the most powerful antioxidant among the extracts tested.

Table 2 summarises the effect of infection on survivorship of $B$. alexandrina in the presence and absence of ethyl acetate extract from E. camaldulensis. The survivorship of infected snails was by almost $9 \%$ lower than that of the control, being $66.6 \%$ and $75 \%$, respectively. However, the infected snails treated with the extract showed a marked improvement in their survivorship even compared to the control: $82 \%$. On the other hand, the infection rate was significantly reduced from $77 \%$ in the snails infected without prior treatment to $20 \%$ in those treated.

Table 1. Free radical scavenging antioxidant activities (DPPH) of $85 \%$ methanolic extract of E. camaldulensis leaves and its derived sub-fractions

\begin{tabular}{lc}
\hline \multicolumn{1}{c}{ Sample } & DPPH $\left(\mathrm{SC}_{50}\right)^{\mathrm{a}}[\mu \mathrm{g} / \mathrm{ml}]$ \\
\hline $85 \%$ Methanol & $65.60 \pm 0.26$ \\
Petroleum ether & N.D. \\
Methylene chloride & N.D. \\
Ethyl acetate & $1.58 \pm 0.29$ \\
$n$-Butanol & $30.64 \pm 0.15$ \\
$\mathrm{H}_{2} \mathrm{O}$ & $102.37 \pm 0.36$ \\
Ascorbic acid & $7.50 \pm 0.32$ \\
\hline
\end{tabular}

Data expressed as mean values \pm standard deviation $(n=3)$. ${ }^{a} \mathrm{DPPH}$ values expressed as $\mu \mathrm{g}$ dry extract $/ \mathrm{ml}(\mu \mathrm{g} / \mathrm{ml})$.

N.D.: Not determined.

\section{STATISTICAL ANALYSIS}

Each experiment was performed in three replicates and the results were presented as mean values \pm standard error of the mean (mean \pm SE). To detect significant differences among the treatments, we used ANOVA followed by post hoc Tukey comparison test; the differences were considered significant at $\mathrm{P}<0.05$. The data were analysed using SPSSv20 (IBM Corporation, NY, USA) and Microsoft Excel 2007 (Microsoft Corporation, Redmond, WA, USA). The levels of significance were defined as: ${ }^{*} \mathrm{P} \leq 0.05$ : slightly significant; ${ }^{* *} \mathrm{P} \leq 0.01$ : significant; ${ }^{* * *} \mathrm{P} \leq 0.001$ : highly significant.

Table 2. Survivorship and infection rates of different experimental groups of Biomphalaria alexandrina

\begin{tabular}{lcc}
\hline \multicolumn{1}{c}{ Group } & Survivorship (\%) & Infection rate (\%) \\
\hline Control & $75 \pm 1.00^{* *}$ & - \\
Infected untreated & $66.60 \pm 2.15^{* *}$ & $77.30 \pm 3.70$ \\
Infected treated & $82.30 \pm 2.35^{* *}$ & $20.00 \pm 2.00^{* * *}$ \\
\hline
\end{tabular}

Data expressed as mean values \pm standard deviation $(n=3)$.

*Significant at $\mathrm{P}<0.001$ (infected treated compared to infected only).

\section{EFFECT OF ETHYL ACETATE EXTRACT FROM E. CAMALDULENSIS ON THE ANTIOXIDANT SYSTEM OF B. ALEXANDRINA}

The modulatory effects of the ethyl acetate extract from E. camaldulensis against infection with S. mansoni in B. alexandrina was evaluated through determination of lipid peroxidation (as MDA concentrations) as a representative of oxidative stress and CAT activity and GSH concentration as representatives of the snail's antioxidant system. In the haemolymph, the levels of MDA were slightly higher in the infected untreated and infected treated groups than those recorded in the control on $1 \mathrm{dpi}$ with a minimal reduction in the treated snails compared to the non-treated (infected). However, on $10 \mathrm{dpi}$, while the MDA levels showed a similar increase in the infected untreated and infected treated groups vs. control, the MDA concentration was higher in the treated than in the untreated group. The situation was completely different during the patent, shedding phase (30 dpi). While infection caused an increase in the level of MDA from $14.77 \pm 1.22 \mathrm{nmol} / \mathrm{ml}$ to $32.24 \pm 0.48$ $\mathrm{nmol} / \mathrm{ml}$, the treatment with the E. camaldulensis extract caused a marked decrease in the MDA level to $22.56 \pm 0.25 \mathrm{nmol} / \mathrm{ml}$. The effect of E. camaldulensis extract on lipid peroxidation was more profound in the tissues than in the haemolymph. It significantly 


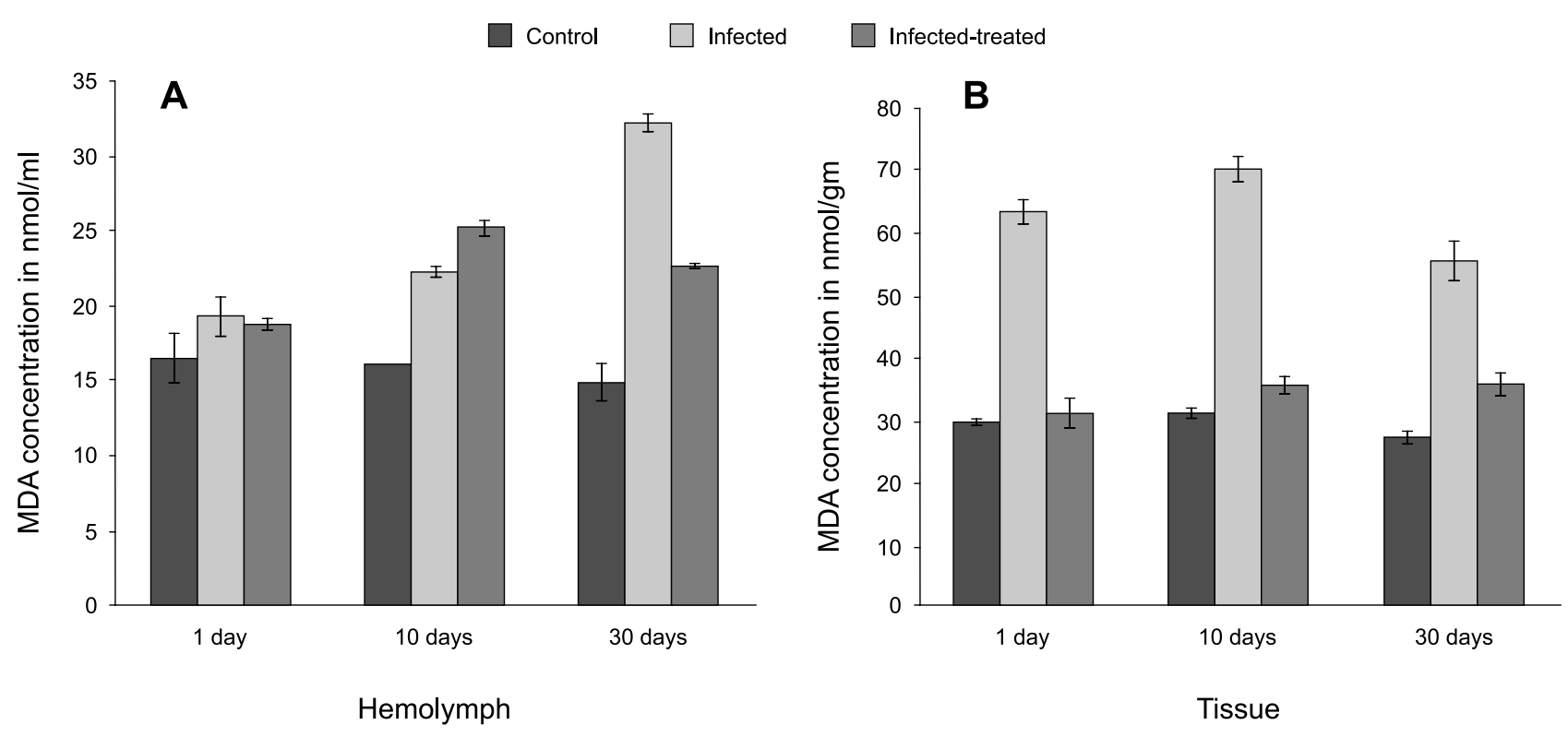

Fig. 1. Lipid peroxidation levels (calculated as malondialdehyde concentration, MDA) in haemolymph and tissue of control, infected untreated and infected treated (exposed to $200 \mathrm{ppm}$ of E. camaldulensis ethyl acetate extract) B. alexandrina on 1, 10, and 30 dpi. Each column represents mean \pm SE of 3 replicate groups

reduced the MDA level nearly to its control values during the prepatent ( $1 \mathrm{dpi}$ and $10 \mathrm{dpi})$ and patent (30 dpi) periods. For example, the MDA level on 10 dpi was $70.20 \pm 2.04 \mathrm{nmol} / \mathrm{gm}$ in the infected untreated group compared to $35.38 \pm 1.70 \mathrm{nmol} / \mathrm{gm}$ in the infected treated group (Fig. 1).

With regard to the antioxidant system of $B$. alexandrina, the CAT activity was significantly increased in the haemolymph and tissues of the treated snails on 1,10 and $30 \mathrm{dpi}$. The CAT activity was increased from $844.44 \pm 40.98 \mathrm{U} / \mathrm{L}$ in the haemolymph of the infected group to $965.27 \pm 15.30 \mathrm{U} / \mathrm{L}$ on $10 \mathrm{dpi}$ and $770.83 \pm 7.21 \mathrm{U} / \mathrm{L}$ to $973.61 \pm 13.60 \mathrm{U} / \mathrm{L}$ in the haemolymph of infected untreated and infected treated groups, respectively. In the tissue, at the same time intervals, the extract had a greater effect on the CAT activity. The extract restored the activity to levels close to the normal control values, as observed on $30 \mathrm{dpi}$ in the infected treated group where it was $4.67 \pm 0.15 \mathrm{U} / \mathrm{gm}$ compared to $3.62 \pm 0.10$ $\mathrm{U} / \mathrm{gm}$ in the infected group and $5.66 \pm 0.54 \mathrm{U} / \mathrm{gm}$ in the control. On $10 \mathrm{dpi}$, the extract increased the

$\square$ Control $\quad \square$ Infected $\quad \square$ Infected-treated
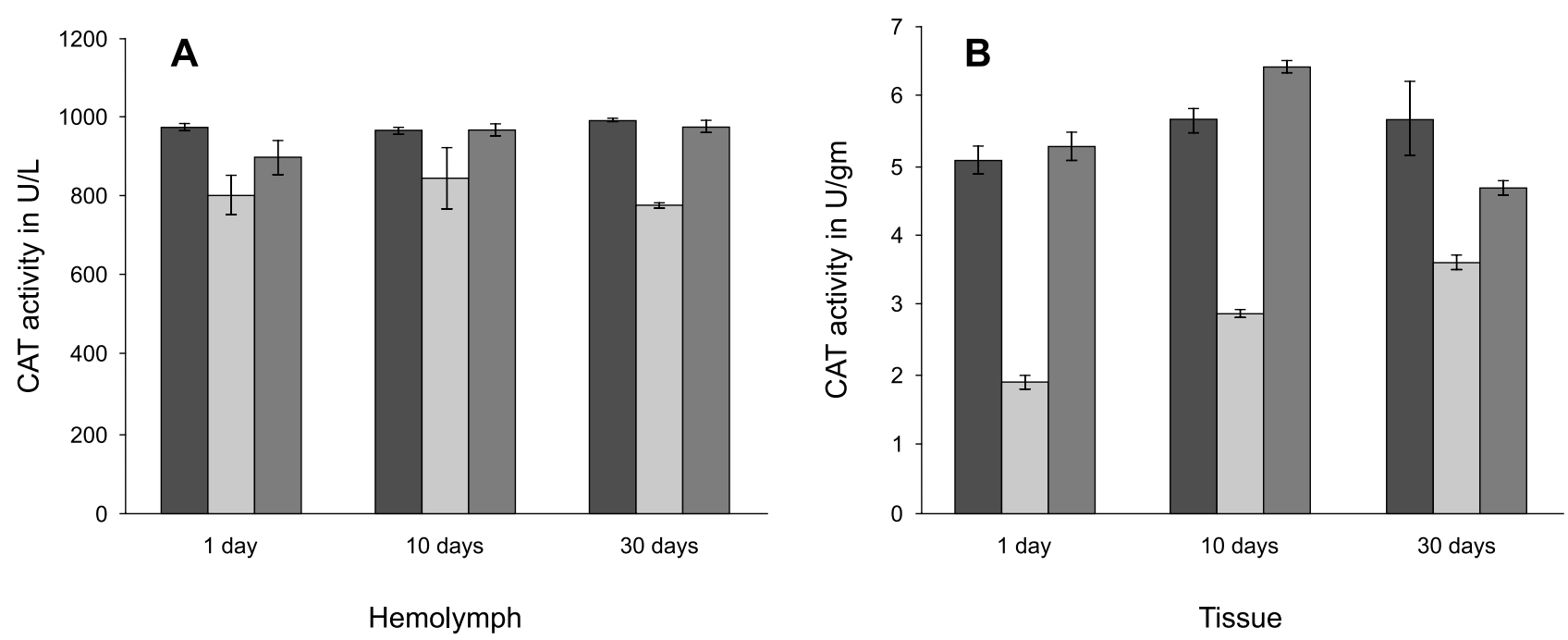

Fig. 2. Catalase (CAT) activity in haemolymph and tissue of control, infected untreated and infected treated (exposed to $200 \mathrm{ppm}$ of E. camaldulensis ethyl acetate extract) B. alexandrina on 1, 10, and 30 dpi. Each column represents mean \pm SE of 3 replicate groups 


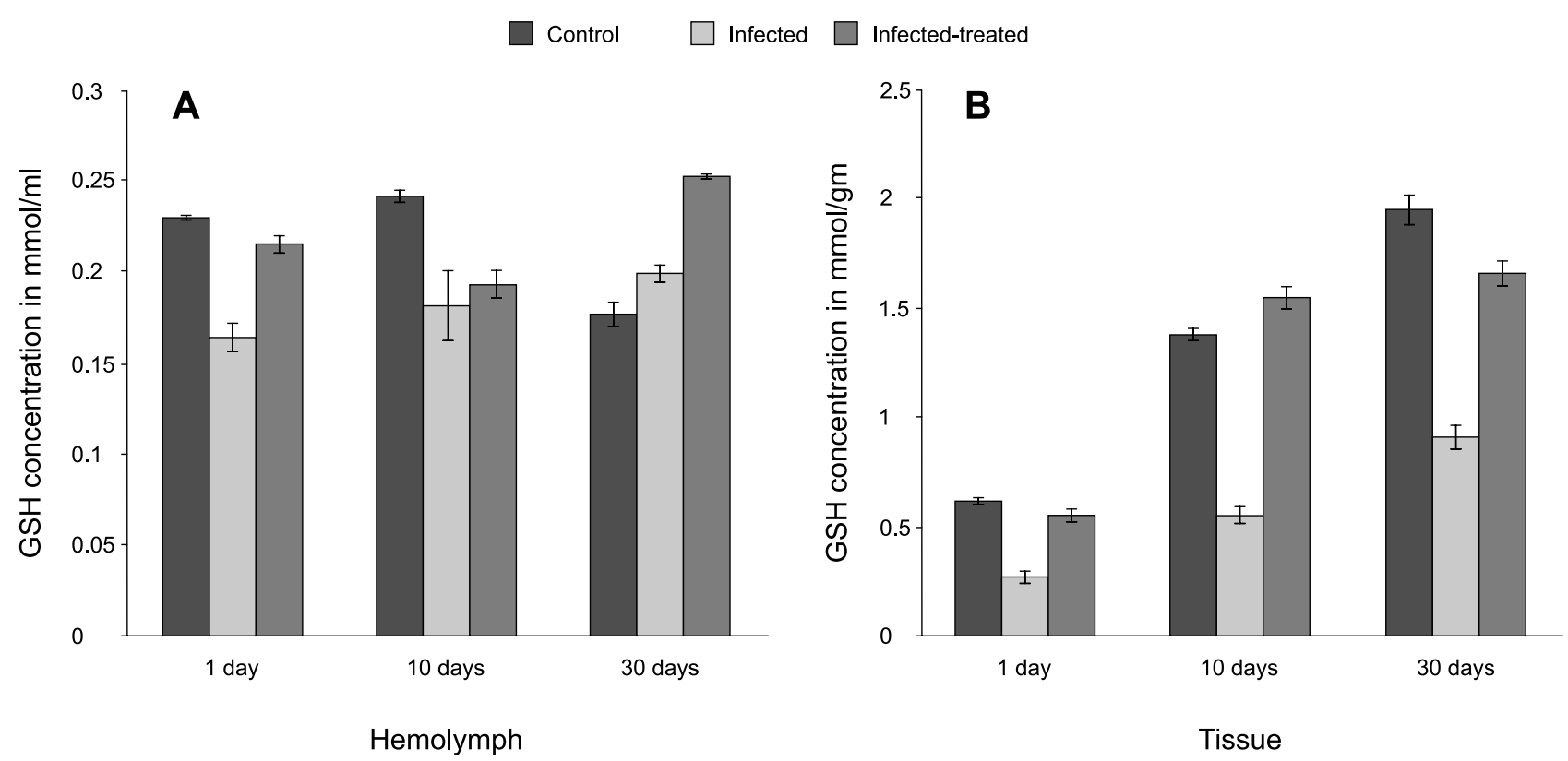

Fig. 3. Concentration of glutathione reduced (GSH) in haemolymph and tissue of control, infected untreated and infected treated (exposed to $200 \mathrm{ppm}$ of E. camaldulensis ethyl acetate extract) B. alexandrina on 1, 10, and 30 dpi. Each column represents mean $\pm \mathrm{SE}$ of 3 replicate groups

CAT activity to twice its value in the infected group: it was $2.86 \pm 0.03$ and $6.39 \pm 0.08 \mathrm{U} / \mathrm{gm}$ in the infected untreated and the infected treated groups, respectively, compared to $5.65 \pm 0.16 \mathrm{U} / \mathrm{gm}$ in the control (Fig. 2). The same pattern was also observed for GSH following the extract treatment. The effect was stronger in the tissues than in the haemolymph (Table 3 and Fig. 3).

Table 3. Levels of malondialdehyde (MDA), catalase (CAT) and reduced glutathione (GSH) in tissue and haemolymph of different experimental groups of Biomphalaria alexandrina

\begin{tabular}{|c|c|c|c|c|c|}
\hline $\begin{array}{l}\text { Oxidative } \\
\text { parameter }\end{array}$ & Intervals & Sample & Control & Infected & Infected-treated \\
\hline \multirow[t]{6}{*}{ MDA } & 1 day & Haemolymph & $16.504 \pm 1.635$ & $19.233 \pm 1.405^{* *}$ & $18.702 \pm 0.332^{* * *}$ \\
\hline & & Tissue & $29.977 \pm 0.080$ & $63.606 \pm 1.597^{* * *}$ & $31.100 \pm 2.336^{* *}$ \\
\hline & 10 days & Haemolymph & $16.106 \pm 0.051$ & $22.124 \pm 0.511^{* *}$ & $25.133 \pm 0.460^{* * *}$ \\
\hline & & Tissue & $31.138 \pm 0.730$ & $70.206 \pm 2.044^{* * *}$ & $35.383 \pm 1.703^{* * *}$ \\
\hline & 30 days & Haemolymph & $14.779 \pm 1.226$ & $32.242 \pm 0.486^{* * *}$ & $22.566 \pm 0.255^{* * *}$ \\
\hline & & Tissue & $27.268 \pm 1.008$ & $55.752 \pm 2.810^{* * *}$ & $36.192 \pm 1.279^{* * *}$ \\
\hline \multirow[t]{6}{*}{ CAT } & 1 day & Haemolymph & $970.833 \pm 4.009$ & $801.667 \pm 51.320^{* * *}$ & $891.667 \pm 35.8^{* * *}$ \\
\hline & & Tissue & $5.061 \pm 0.223$ & $1.905 \pm 0.105^{* * *}$ & $5.269 \pm 0.215^{*}$ \\
\hline & 10 days & Haemolymph & $962.500 \pm 5.613$ & $844.444 \pm 40.980^{* * *}$ & $965.278 \pm 15.23^{* * *}$ \\
\hline & & Tissue & $5.655 \pm 0.160$ & $2.863 \pm 0.037^{* * *}$ & $6.398 \pm 0.087^{* * *}$ \\
\hline & 30 days & Haemolymph & $988.889 \pm 1.604$ & $770.833 \pm 7.217^{* * *}$ & $973.611 \pm 13.63^{* * *}$ \\
\hline & & Tissue & $5.667 \pm 0.545$ & $3.622 \pm 0.100^{* * *}$ & $4.674 \pm 0.105^{* * *}$ \\
\hline \multirow[t]{6}{*}{ GSH } & 1 day & Haemolymph & $0.229 \pm 0.001$ & $0.164 \pm 0.007^{* * *}$ & $0.215 \pm 0.004^{* * *}$ \\
\hline & & Tissue & $0.618 \pm 0.014$ & $0.270 \pm 0.036^{* * *}$ & $0.555 \pm 0.020^{* * *}$ \\
\hline & 10 days & Haemolymph & $0.242 \pm 0.003$ & $0.181 \pm 0.021^{* * *}$ & $0.193 \pm 0.006^{* * *}$ \\
\hline & & Tissue & $1.380 \pm 0.027$ & $0.554 \pm 0.034^{* * *}$ & $1.554 \pm 0.043^{*}$ \\
\hline & 30 days & Haemolymph & $0.176 \pm 0.007$ & $0.198 \pm 0.006^{*}$ & $0.251 \pm 0.003^{*}$ \\
\hline & & Tissue & $1.954 \pm 0.064$ & $0.916 \pm 0.048^{* * *}$ & $1.652 \pm 0.057^{* * *}$ \\
\hline
\end{tabular}

Data presented as mean \pm standard error $(\mathrm{SE})$.

* slightly significant $\mathrm{P} \leq 0.05$; significant ${ }^{* *} 0.001<\mathrm{P} \leq 0.01$; ${ }^{* * *}$ highly significant $\mathrm{P} \leq 0.001$ compared to control and infected groups. 


\section{DISCUSSION}

The present study represents a new direction in the control of one of the medically important freshwater snails, B. alexandrina, the snail responsible for transmission of intestinal schistosomiasis in Egypt. Most of the control strategies of schistosomiasis focus mainly on mass drug administration to decrease the disease incidence, although snail control has been shown important in schistosomiasis elimination. The currently applied control methods have some disadvantages, such as the emerging resistance to praziquantel in the laboratory (FALLON \& DOENHOFF 1994, WANG et al. 2012) and environmental and financial problems related to chemical molluscicides (KING \& BERTSCH 2015). There is a continuous need for new control initiatives. Controlling the parasite during its intramolluscan stage using antioxidant plants might be an easy and environment-friendly method. For this purpose, it is mandatory to expand our knowledge of the Biomphalaria-Schistosoma system as well as the factors exploited by the host and parasite and responsible for the success or failure of infection.

One of the biochemical machineries involved in the snail-schistosome interactions, is reactive oxygen species (ROS). Haemocytes of Biomphalaria quickly recognise parasites and produce ROS to kill the invading pathogens. This is an important component of Biomphalaria cellular defences; it determines the susceptibility or resistance to schistosome infection and production of cercariae (BENDER et al. 2007, YOSHINO et al. 2008, ITTIPRASERT et al. 2010, MONÉ et al. 2011). Interference with the snail immune system through improving the antioxidant system may help the snails to overcome the infection-associated stress and finally lead to retarding parasite development.

Natural plant products are rich in antioxidants such as phenolic, polyphenolic, alkaloid, quinone, and terpenoid molecules (HUANG et al. 2009, ZHANG et al. 2011). These products have been used to improve immune responses to infection (COWAN 1999, HARIKRISHNAN et al. 2011). E. camadulensis is a wellknown species which is widespread in Egypt and has been used for many medicinal purposes (SINGAB et al. 2011). Its leaves were collected and extracted with different solvents and the antioxidant capacity for each solvent extract was compared using the DPPH assay. The results showed that the most powerful extract was ethyl acetate; consequently, it was used in the biological experiments to test its anti-parasitic effect against $S$. mansoni in B. alexandrina. The treatment of infected Biomphalaria with E. camaldulensis extract improved the snails' survivorship and significantly reduced the infection rate to $20 \%$ compared to $77 \%$ in the infected untreated snails.
Moreover, by studying the influence of the extract on different oxidative stress and antioxidant parameters, it was found that the ethyl acetate extract of E. camaldulensis exhibited a modulatory effect on the level of lipid peroxidation where it reduced the MDA concentration in both the haemolymph and the tissues of infected treated snails compared to those infected without treatment. On $30 \mathrm{dpi}$, the level of MDA was $32.24 \pm 0.48 \mathrm{nmol} / \mathrm{ml}$ in the haemolymph of infected untreated snails compared to $22.56 \pm 0.25 \mathrm{nmol} /$ $\mathrm{ml}$ in infected treated ones. Moreover, the effect of the extract on lipid peroxidation was more obvious in the tissues where it significantly reduced the MDA levels to values close to that of control on 1, 10, 30 dpi (Table 3).

Besides decreasing the infection-associated oxidative stress (lipid peroxidation), E. camaldulensis had a positive effect on the antioxidant system of Biomphalaria. It significantly improved the haemolymph and tissue concentration of CAT on 1, 10 and $30 \mathrm{dpi}$. The increase in the enzyme activity was greater in the tissues of the treated snails than in their haemoplymph. The extract restored the activity to levels close to the normal control values; on $30 \mathrm{dpi}$ in the infected treated group the CAT activity was $4.67 \pm 0.15 \mathrm{U} / \mathrm{gm}$ compared to $3.62 \pm 0.10 \mathrm{U} / \mathrm{gm}$ in the infected group and $5.66 \pm 0.54 \mathrm{U} / \mathrm{gm}$ in the control. The GSH concentrations were also increased following the extract treatment in a similar manner to CAT (Table 3 and Fig. 3).

Earlier results clearly indicated that E. camaldulensis had an antischistosomal effect against $S$. mansoni in B. alexandrina, as demonstrated by the increase in the snails' survivorship following infection and the reduction of the infection rate. This reduction is supported by the biochemical data obtained. The reduction in lipid peroxidation and increase in CAT and GSH reflect an improvement in the immune status and may account for this drop in infection rate. The previous studies showed that hydrogen peroxide $\left(\mathrm{H}_{2} \mathrm{O}_{2}\right)$, the most predominant ROS molecule produced by haemocytes and involved in killing larvae of S. mansoni in snails, is generated by $\mathrm{Cu} / \mathrm{Zn} \mathrm{SOD}$, and the snails' ability to eliminate schistosome infection depends on their capacity to generate extracellular $\mathrm{H}_{2} \mathrm{O}_{2}$ (BENDER et al. 2005). To overcome the ROS produced by the snails, the parasites produce antioxidant molecules (CONNORS et al. 1991, VERMEIRE \& YOSHINO 2007). Sporocysts produce antioxidant enzymes, such as glutathione-S-transferase, $\mathrm{Cu} / \mathrm{Zn}$ and Mn SODs, glutathione peroxidase and peroxiredoxins, to protect themselves from oxidative damage (MOURÃo et al. 2009, WU et al. 2009). Apparently, E. camaldulensis exerted its effect in a different mechanism possibly by increasing the overall antioxidant 
status of the snails and improving the haemocyte capacity to encounter and degrade the parasite larvae. In the same context, treatment with Eucalyptus globulus oil extract had an effect on the phagocytotic ability of human monocyte-derived macrophages in the presence of immuno-suppression induced by the chemotherapeutic agent 5-fluorouracil (5-FU). Combined treatment with 5-FU/Eucalyptus oil extract inhibited the 5-FU-induced myelotoxicity and raised the phagocytotic activity of the granulocytic/monocytic system, significantly decreased by the chemotherapy (SERAFINO et al. 2008).

Various biological effects of Eucalyptus have been documented, including antimicrobial, and antihyperglycemic properties (TAKAHASHI et al. 2004, GILLES et al. 2010). Moreover, it has been reported that extracts from E. camaldulensis have an antitrichomonas effect (DE BRUM VIEIRA et al. 2015). HASSANI et al. (2013) found that the ethyl acetate fraction of E. camaldulensis showed $100 \%$ growth inhibition for Trichomonas vaginalis in culture medium at $12.5 \mathrm{mg} /$ $\mathrm{ml}$ concentration after 24 and $48 \mathrm{~h}$. Alcoholic and oil extracts from leaves of E. camaldulensis had an antileishmanial effect on Leishmania major promastigotes form (NOSRATABADI et al. 2015). Aqueous extracts of Eucalyptus showed the highest activity

\section{CONCLUSION}

It can be concluded that the ethyl acetate extract from leaves of E. camaldulensis can be used as antiparasitic compound against intramolluscan phase of $S$. mansoni. The plant is widespread in many sub-urban areas of Egypt which are more tolerant to schistosomiasis infection. Its use to control schistosomiasis prevalence in snails may overcome many of the financial and environmental concerns associated with

\section{REFERENCES}

ABOU-El-NAGA I. F. 2013. Biomphalaria alexandrina in Egypt: Past, present and future. J. Biosci. 38: 665-672. https:// doi.org/10.1007/s12038-013-9329-4

AEBI H. 1984. Catalase in vitro. Methods Enzymol. 105: 121126. https://doi.org/10.1016/S0076-6879(84)05016-3

AL-SAIMARY I. E., ZEKI A. 1999. In vitro chemotherapeutic effects of antibiotics and plant extract on protoscoleces viability of human hydatid cysts. J. Basrah Res. 20: 79-98.

AMAKURA Y., UMino Y., TSUjI S., ITO H., Hatano T., YoshidA T., TONOGAI Y. 2002. Constituents and their antioxidative effects in Eucalyptus leaf extract used as a natural food additive. Food Chem. 77: 47-56. https:// doi.org/10.1016/S0308-8146(01)00321-1

BATISH D. R., Singh H. P., KoHLi R. K., KAUR S. 2008. Eucalyptus essential oil as a natural pesticide. Forest Ecol. against protoscolices of human Echinococcus granulosus; it decreased the viability to $0 \%$ in $72 \mathrm{~h}$ (ALSAIMARY \& ZEKI 1999). Microscopic observation showed that the essential oil from produced by the leaves of E. camaldulensis caused severe damage in S. mansoni worm's typography (EL-BAZ et al. 2015). Also, it had a powerful inhibitory effect against larvae of two mosquito species: Aedes aegypti and A. albopictus (CHENG et al. 2009).

Separation and characterisation of the phytoconstituents of the aqueous acetone leaf extract of $E$. camaldulensis identified fifty-six compounds, including ellagitannins, flavonoids, phloroglucinol derivatives and galloylesters. Most of the fractions separated from the plant exhibited a strong antioxidant and anti-tumor activities (SINGAB et al. 2011). WONG-PAZ et al. (2015) found that the antioxidant activity of E. camaldulensis extract was correlated with the high total phenolic content observed during its quantification in the extraction process. Moreover, AMAKURA et al. (2002) evaluated the antioxidant activity of Eucalyptus extract by the DPPH assay and observed that terpenes and phloroglucinol isolated from E. camaldulensis had a higher antioxidant activity than synthetic antioxidants.

chemical molluscicides as well as biodiversity change as a result of snail eradication.

\section{ACKNOWLEDGEMENT}

We thank the internal projects committee of the Theodor Bilharz Research Institute, Egypt, for their approval of project No. 100M.

Manag. 256: 2166-2174. https://doi.org/10.1016/j. foreco.2008.08.008

BAYNE C. J. 2009. Successful parasitism of vector snail Biomphalaria glabrata by the human blood fluke (trematode) Schistosoma mansoni: a 2009 assessment. Mol. Biochem. Parasitol. 165: 8-18. https://doi. org/10.1016/j.molbiopara.2009.01.005

BAYNE C. J., BuCKLEY P. M., DEWAN P. C. 1980. Macrophagelike hemocytes of resistant Biomphalaria glabrata are cytotoxic for sporocysts of Schistosoma mansoni in vitro. J. Parasitol. 66: 413-419. https://doi. org/10.2307/3280740

Bender R. C., Broderick E. J., GoOdAll C. P., BAyne C. J. 2005. Respiratory burst of Biomphalaria glabrata hemocytes: Schistosoma mansoni-resistant snails produce more extracellular $\mathrm{H}_{2} \mathrm{O}_{2}$ than susceptible snails. J. 
Parasitol. 91: 275-279. https://doi.org/10.1645/GE415R

Bender R. C., Goodall C. P., Blouin M. S., BAYNe C. J. 2007. Variation in expression of Biomphalaria glabrata SOD1: a potential controlling factor in susceptibility/resistance to Schistosoma mansoni. Develop. Comp. Immunol. 31: 874-878. https://doi.org/10.1016/j. dci.2006.12.005

Beutler E., Duron O., Kellin B. M. 1963. Improved method for the determination of blood glutathione. J. Lab. Clin. Med. 61: 882-888.

BRUM VieIRA P. DE, GIORDANI R. B., MACEDO A. J., TASCA T. 2015. Natural and synthetic compound anti-Trichomonas vaginalis: an update review. Parasitol. Res. 114: 12491261. https://doi.org/10.1007/s00436-015-4340-3

CARVAlHo I. T., EstevinHo B. N., SANTOS L. 2016. Application of microencapsulated essential oils in cosmetic and personal healthcare products - a review. Int. J. Cosm. Sci. 38: 109-119. https://doi.org/10.1111/ ics. 12232

Cheng S. S., Huang C. G., Chen Y. J., Yu J. J., Chen W. J., Chang S. T. 2009. Chemical compositions and larvicidal activities of leaf essential oils from two eucalyptus species. Biores. Technol. 100: 452-456. https://doi. org/10.1016/j.biortech.2008.02.038

CHERnin E., DunAVAN C. A. 1962. The influence of hostparasite dispersion upon the capacity of Schistosoma mansoni miracidia to infection Australorbis glabratus. Amer. J. Trop. Med. Hyg. 11: 455-471. https://doi. org/10.4269/ajtmh.1962.11.455

CONNORS V. A., LODES M. J., Yoshino T. P. 1991. Identification of a Schistosoma mansoni sporocyst excretory-secretory antioxidant molecule and its effect on superoxide production by Biomphalaria glabrata hemocytes. J. Invert. Pathol. 58: 387-395. https://doi. org/10.1016/0022-2011(91)90185-S

COWAN M. M. 1999. Plant products as antimicrobial agents. Clin. Microbiol. Rev. 12: 564-582.

DeY B., MitRA A. 2013. Chemo-profiling of eucalyptus and study of its hypoglycemic potential. World J. Diabetes 4: 170. https://doi.org/10.4239/wjd.v4.i5.170

Doenhoff M. J., Hagan P., Cioli D., SOUThGate V., PiCAMATtoccia L., Botros S., COLES G., TCHUEMTCHUENTÉ L. A., MBAYE A., ENGELS D. 2009. Praziquantel: its use in control of schistosomiasis in sub-Saharan Africa and current research needs. Parasitology 136: 1825-1835. https://doi.org/10.1017/S0031182009000493

El-BAZ F. K., MAHMOUD K., EL-SENOUSY W. M., DARWESH O. M., ElGOHARY A. E. 2015: Antiviral-antimicrobial and schistosomicidal activities of Eucalyptus camaldulensis essential oils. Int. J. Pharm. Sci. Rev. Res. 31: 262268.

FAllon P. G., DoenhofF M. J. 1994. Drug-resistant schistosomiasis: resistance to praziquantel and oxamniquine induced in Schistosoma mansoni in mice is drug specific. Am. J. Trop. Med. Hyg. 51: 83-88. https://doi. org/10.4269/ajtmh.1994.51.83

Ghareeb M. A., Shoeb H. A., Madkour H. M., Refaey L. A., MOHAmed M. A., SAAD A. M. 2014. Antioxidant and cytotoxic activities of Tectona grandis Linn leaves. Int. J. Phytopharmacol. 5: 143-157.
GHISALBERTI E. L. 1996. Bioactive acylphloroglucinol derivatives from Eucalyptus species. Phytochemistry 41: 7-22. https://doi.org/10.1016/0031-9422(95)00484-X

Gilles M., ZHAO J., AN M., AgBoOla S. 2010. Chemical composition and antimicrobial properties of essential oils of three Australian Eucalyptus species. Food Chem. 119: 731-737. https://doi.org/10.1016/j.foodchem.2009.07.021

Haggag A. A., Rabiee A., Elaziz K. M. A., Gabrielli A. F., HAY R. A., RAMZY R. M. 2017. Mapping of Schistosoma mansoni in the Nile Delta, Egypt: Assessment of the prevalence by the circulating cathodic antigen urine assay. Acta Trop. 167: 9-17. https://doi.org/10.1016/j. actatropica.2016.11.038

HAHN U. K., BENDER R. C., BAYNE C. J. 2001. Killing of Schistosoma mansoni sporocysts by hemocytes from resistant Biomphalaria glabrata: role of reactive oxygen species. J. Parasitol. 87: 292-299. https://doi.org/10. 1645/0022-3395(2001)087[0292:KOSMSB]2.0.CO;2

HARIKRISHNAN R., BALASUNDARAM C., HEO M. S. 2011. Impact of plant products on innate and adaptive immune system of cultured finfish and shellfish. Aquaculture 317: 1-15. https://doi.org/10.1016/j. aquaculture.2011.03.039

HASSANI S., ASGHARI G., YOUSEFI H., KAZEMIAN A., RAFIEIEAN M., DARANI H. Y. 2013. Effects of different extracts of Eucalyptus camaldulensis on Trichomonas vaginalis parasite in culture medium. Adv. Biomed. Res. 2: 47. https://doi.org/10.4103/2277-9175.114187

HUANG W. Y., CAI Y.Z., ZHANG Y. 2009. Natural phenolic compounds from medicinal herbs and dietary plants: potential use for cancer prevention. Nutr. Cancer 62: 1-20. https://doi.org/10.1080/01635580903191585

ItTiprasert W., Miller A., Myers J., Nene V., El-SAyed N. M., KNIGHT M. 2010. Identification of immediate response genes dominantly expressed in juvenile resistant and susceptible Biomphalaria glabrata snails upon exposure to Schistosoma mansoni. Mol. Biochem. Parasitol. 169: 27-39. https://doi.org/10.1016/j.molbiopara.2009.09.009

KING C. H., BERTSCH D. 2015. Historical perspective: snail control to prevent schistosomiasis. PLoS Negl. Trop. Dis. 9(4): e0003657. https://doi.org/10.1371/journal. pntd.0003657

LAMBERT R. J., SKANDAMIS P. N., COOTE P. J., NyCHAS G. J. 2001. A study of the minimum inhibitory concentration and mode of action of oregano essential oil, thymol and carvacrol. J. Appl. Microbiol. 91: 453-462. https:// doi.org/10.1046/j.1365-2672.2001.01428.x

LOTFY W. M., DeJONG R. J., ABDEl Kader A. A., LOKER E. S. 2005. A molecular survey of Biomphalaria in Egypt: Is B. glabrata present? Amer. J. Trop. Med. Hyg. 73: 131-139.

MEULEMAN E. A. 1971. Host-parasite interrelationships between the freshwater pulmonate Biomphalaria pfeifferi and the trematode Schistosoma mansoni. Neth. J. Zool. 22: 355-427. https://doi.org/10.1163/002829672X00013

MitTa G., Gourbal B., Grunau C., KNight M., Bridger J. M., THÉRON A. 2017. Chapter Three. The compatibility between Biomphalaria glabrata snails and Schistosoma mansoni: an increasingly complex puzzle. Adv. Parasitol. 97: 111-145. https://doi.org/10.1016/bs.apar.2016.08.006 
Mohamed A. H., Sharaf El-Din A. T., Mohamed A. M. HABIB M. R. 2012. The relationship between genetic variability and the susceptibility of Biomphalaria alexandrina snails to Schistosoma mansoni infection. Mem. Inst. Oswaldo Cruz 107: 326-337. https://doi.org/10.1590/ S0074-02762012000300006

Moné Y., Ribou A. C., Cosseau C., Duval D., Théron A., MitTA G., Gourbal B. 2011. An example of molecular co-evolution: reactive oxygen species (ROS) and ROS scavenger levels in Schistosoma mansoni/Biomphalaria glabrata interactions. Int. J. Parasitol. 41: 721-730. https:// doi.org/10.1016/j.ijpara.2011.01.007

Morgan J. A. T., DeJONG R. J., SNyder S. D., MKojI G. M., LOKER E. S. 2001. Schistosoma mansoni and Biomphalaria: past history and future trends. Parasitology 123: 211228. https://doi.org/10.1017/S0031182001007703

Mossalem H. S., GHAReEB M. A., ReFFAHY L. A., MOHAMED A. S., HABIB M. R. 2017. GAS Chromatography-Mass spectrometry analysis and antioxidant activity of Punica geranium L. Peels and its role as immunostimulant against Schistosoma mansoni infection in Biomphalaria alexandrina. Asian J. Pharm. Clin. Res. 10: 1-7.

Mourão M. M., Dinguirard N., Franco G. R., Yoshino T. P. 2009. Role of the endogenous antioxidant system in the protection of Schistosoma mansoni primary sporocysts against exogenous oxidative stress. PLoS Negl. Trop. Dis. 3: e550. https://doi.org/10.1371/journal. pntd.0000550

NeElam A., Hany O., Sherwani S. K., JabeEN S., NANGYAL H. 2014. Phytochemical and bioactivity of commercially available Eucalyptus oil against human pathogens. South Asian J. Life Sci. 2: 8-11. https://doi. org/10.14737/journal.sajls/2014/2.1.8.11

Nerio L. S., Olivero-Verbel J., StASHENKO E. 2010. Repellent activity of essential oils: a review. Biores. Technol. 101: 372-378. https://doi.org/10.1016/j.biortech.2009.07.048

NOSRATABADI S. J., SHARIFI I., SHARIFIFAR F., BAMOROVAT M., DANESHVAR H., MiRZAIE M. 2015. In vitro antileishmanial activity of methanolic and aqueous extracts of Eucalyptus camaldulensis against Leishmania major. J. Parasit. Dis. 39: 18-21. https://doi.org/10.1007/ s12639-013-0377-3

Pino J. A., Marbot R., Quert R., Garcia H. 2002. Study of essential oils of Eucalyptus resinifera, E. tereticornis and Corymbia maculata (Hook.) grown in Cuba. Flavour. Frag. J. 17: 1-14. https://doi.org/10.1002/ffj.1026

SATOH K. 1978. Serum lipid peroxide in cerebrovascular disorders determined by a new colorimetric method. Clin. Chim. Acta 90: 37-43. https://doi.org/10.1016/00098981(78)90081-5

SERAFino A., VALlebona P. S., ANDREOla F., ZONFRILlO M., MERCURI L., FEDERIC M., RASI G., GARACI E., PIERIMARCHI P. 2008. Stimulatory effect of Eucalyptus essential oil on innate cell-mediated immune response. BMC Immunol. 9: 17. https://doi. org/10.1186/1471-2172-9-17

Shoeb H. A., MadKour H. M. F., Refahy L. A., MoHAmed M. A., SAad A. M., GHareeb M. A. 2014. Antioxidant and cytotoxic activities of Gmelina arborea (ROXB.) leaves. Br. J. Pharm. Res. 4: 125-144. https://doi. org/10.9734/BJPR/2014/6018
Singab A. N., Ayoub N., Al-Sayed E., Martiskainen O., SinkKONEN J., PIHLAJA K. 2011. Phenolic constituents of Eucalyptus camaldulensis Dehnh, with potential antioxidant and cytotoxic activities. Record Nat. Prod. 5: 271.

SIRAMON P., OHTANI Y. 2007. Antioxidative and antiradical activities of Eucalyptus camaldulensis leaf oils from Thailand. J. Wood Sci. 53: 498-504. https://doi. org/10.1007/s10086-007-0887-7

SiRAMON P., OHTANI Y., ICHIURA H. 2009. Biological performance of Eucalyptus camaldulensis leaf oils from Thailand against the subterranean termite Coptotermes formosanus Shiraki. J. Wood Sci. 55: 41-46. https://doi. org/10.1007/s10086-008-0990-4

SOKOlOW S. H., WOOD C. L., JONES I. J., SWARTZ S. J., LOPEZ M., HSIEH M. H., LAfFerTy K. D., KuRIS A. M., Rickards C., DE LEO G. A. 2016. Global assessment of schistosomiasis control over the past century shows targeting the snail intermediate host works best. PLoS Negl. Trop. Dis. 10: e0004794. https://doi. org/10.1371/journal.pntd.0004794

TAKAHASHI T., KOKUBO R., SAKAINO M. 2004. Antimicrobial activities of eucalyptus leaf extracts and flavonoids from Eucalyptus maculata. Lett. Appl. Microbiol. 39: 60-64. https://doi.org/10.1111/j.1472 765X.2004.01538.x

Vermeire J. J., Yoshino T. P. 2007. Antioxidant gene expression and function in in vitro-developing Schistosoma mansoni mother sporocysts: possible role in self-protection. Parasitology 134: 1369-1378. https://doi. org/10.1017/S0031182007002697

WANG W., WANG L., LIANG Y. S. 2012. Susceptibility or resistance of praziquantel in human schistosomiasis: a review. Parasitol. Res. 111: 1871-1877. https://doi. org/10.1007/s00436-012-3151-z

WONG-PAZ J. E., CONTRERAS-ESQUIVEL J. C., RODRÍGUEZHERRERA R., CARRILlO-INUNGARAY M. L., LÓPEZ L. I., NevÁreZ-Moorillón G. V., Aguilar C. N. 2015. Total phenolic content, in vitro antioxidant activity and chemical composition of plant extracts from semiarid Mexican region. Asian Pacific J. Trop. Med. 8: 104-111. https://doi.org/10.1016/S1995-7645(14)60299-6

WHO (World Health Organization) 2017. Schistosomiasis weekly epidemiological record. WHO, Geneva, Switzerland.

Wu X. J., Sabat G., Brown J. F., Zhang M., Taft A., PETERSON N., HARMS A., YOSHINO T. P. 2009. Proteomic analysis of Schistosoma mansoni proteins released during in vitro miracidium-to-sporocyst transformation. Mol. Biochem. Parasitol. 164: 32-44. https://doi. org/10.1016/j.molbiopara.2008.11.005

Yoshino T. P., Dinguirard N., KUnerT J., HOKKe C. H. 2008. Molecular and functional characterization of a tandem-repeat galectin from the freshwater snail Biomphalaria glabrata, intermediate host of the human blood fluke Schistosoma mansoni. Gene 411: 46-58. https://doi.org/10.1016/j.gene.2008.01.003

YOUSIF F., IBRAHIM A., EL-BARDICY S. N. 1998. Compatibility of Biomphalaria alexandrina, Biomphalaria glabrata and a hybrid of both to seven strains of Schistosoma mansoni from Egypt. J. Egypt Soc. Parasitol. 28: 863-881. 
ZelCK U. E., JANOWSKY B. VON 2004. Antioxidant enzymes in intramolluscan Schistosoma mansoni and ROSinduced changes in expression. Parasitology 128: 493501. https://doi.org/10.1017/S0031182004004895

ZHANG L., RAVIPATI A. S., KOYYALAMUDI S. R., JEONG S. C., REDDY N., SMith P. T., BARTLETT J., ShANMUGAM K., MÜNCH G., WU M. J. 2011. Antioxidant and antiinflammatory activities of selected medicinal plants containing phenolic and flavonoid compounds. J. Agric. Food Chem. 59: 12361-12367.

Received: April 4th, 2018

Revised: May 30th, 2018

Accepted: June 6th, 2018

Published on-line: July 25th, 2018 